\title{
Opinion
}

\section{My 84-Year-Old Mother Lost Her Wedding Ring?}

\author{
Michael S. Kennedy, MDIV, MED HRTD, NCSP, LSSP, CTMH* \\ Licensed Specialist in School Psychology (LSSP), Bryan ISD, Bryan, Texas, USA \\ "Corresponding author \\ Michael S. Kennedy, MDIV, MED HRTD, NCSP, LSSP, CTMH \\ Licensed Specialist in School Psychology (LSSP), Bryan ISD, Bryan, Texas, USA; E-mail: kenmicn@gmail.com
}

\section{Article information}

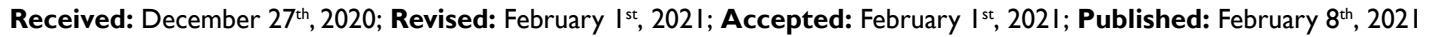

\section{Cite this article}

Kennedy MS. My 84-year-old mother lost her wedding ring? Psychol Cogn Sci Open J. 202I; 7(I): 19-20. doi: I0. 17।40/PCSOJ-7-160

\begin{abstract}
A official website that provides general information for the public about the coronavirus disease 2019 (COVID-19) disease for Tom Green Country in Texas is the City of San Angelo, Texas website. ${ }^{1}$
\end{abstract}

My Mother lived in San Angelo, Texas, which is within Tom Green Country. As of January 27, 2021, there have been 269 deaths in Tom Green County caused by the COVID-19 disease: 110 female and 159 male. As a preventative measure, health care and medical care facilities stated that visitors were not allowed to visit a family member who had a medical diagnosis of the COVID-19 disease. To mitigate the spread of the COVID-19 disease even more, many medical care facilities did not allow visitors into patient's rooms—regardless of medical diagnosis. My Mother died on Sunday, September 27, 2020. I could visit my Mother in person only because a new order regulating visitation, which I provide here, which is provided on the City of San Angelo, Texas:

"Effective September 24th, eligible nursing homes, assisted living facilities, \& long-term care facilities will be able to designate up to two essential family caregivers for visitation to ensure their loved one's needs are being met."

"For general visitors who are not a designated essential caregiver, these updated emergency rules will allow approved facilities to schedule outdoor no contact visits, open window visits, or indoor visitation with the use of plexiglass safety barriers to prevent the spread of COVID-19. Physical contact between residents and general visitors is not permitted. Facilities also must continue to meet all additional visitation requirements outlined in the emergency rules." 1

My Father had moved with my older brother to Atlanta, Georgia a week earlier, partly because he was not allowed to see his wife. While he could stand outside and see his wife through the window, and speak with her via a walkie-talkie, or a cell phone, my Father had Emphysema, and was himself tired, not able to stand for long looking through a window. He also has severe hearing loss, so trying to her with a walkie-talkie, or even a cell phone was very frustrating. He also has macular degeneration in his eyes. Have you ever tried to look through a mess of wire covering a window with macular degeneration? The wire mesh distorts the vision. With these three conditions limiting my Father's satisfaction of "having seen" his wife, he gave up. He gave up trying to "see" his wife. He was not able to "be with his wife." Imagine being married for 65-years. Then, being told, you cannot be with your spouse as a safety measure to prevent the spread of a new virus. Imagine the confusion for the spouse who is ill, isolated in the patient room, learning she cannot be with her spouse. Imagine the confusion of the spouse who cannot be with their spouse who is ill, in many cases, dying, living their last days of their life, in a patient room, not allowed to have an in-person visit from their spouse-of 65-years. What does love feel like then? What do the promises of commitment and honor and cherish, and protecting one's spouse feel like then? Does love overcome the barrier, or does the barrier of a rule for everyone's safety prevent an emotional connection from actualizing? While a safety rule may not overcome an emotional connection between two people, a safety rule does limit the physical connection - the touch, the audible voice of one's spouse heard in the ear, one's family member's physical presence does not happen. Each person realizing that dying alone has new meaning. Connecting via a window, or by a cell phone call, or even by a streaming video connection does quite fulfill a promise that is lived through a lifetime of presence. My Father did not want to see his wife this way. My Father "couldn't" "see" his wife this way; he could not hear her, he could not see her, he could not be with her. I wonder if my Father felt as if had failed her? I wonder if my Father simply gave up because his physical limitations, his weaking endurance, his sadness overcame his desire to be with his wife, when he could not be with her? I wonder what my Mother felt, as she wondered why her husband could not be with her. Did not want to be with her? Could not muster enough strength just for a visit?

While I could not understand all the questions and unanswered feelings my parents must have been experiencing, I knew what I could do, I knew what I must do. I was going to be with my 
Mother. I did not know if I could be in her room when I drove 6 hours to be with her. But I knew I must be with her. I knew I wanted to be with her. When I arrived at the care facility, I am extremely fortunate that the nurse told me that the safety rule of limited visitation had been relaxed just a few days earlier. I could be with my Mother, with a gown, a facial mask, and a plastic face shield, some plastic gloves, and at least four feet of distance between us- for no more than four hours at a time. Yet, I was with her. I knew I could speak to her words of courage. I could look into her eyes. I could use my courage, my faith, to instill within her soul the strength of my soul. I could speak the truth of God's love for her, and I could pray for her. I could smile with my eyes and my mouth, and I could be a source of love and reassurance and faith and hope when she could not be these things for herself. I wanted her to die in my presence. I wanted her to die knowing I loved her, her family loved her. I represented all the other family members who could not be there in person. This is what I wanted for her; this is what I wanted for myself. This is what I wanted for my family. Mostly, this assurance of God's love embodied in my presence for her is what I wanted her to know with no doubt. I pray this love is what she felt. My Mother died on Sunday, September 27, 2020 at 4:50 am, alone, having taken off her wedding ring?

The Centers for Disease Control and Prevention (CDC) website states that as of January 27, 2021, in the United States 88\% of the people dying are dying in a hospital, medical care facility, or a nursing home, or a long-term care facility. At least eighty-eight percent of all people dying today in the United States are impacted by the safety rules of COVID-19. ${ }^{2}$

The John Hopkins University and Medicine website, on the Coronavirus Resource Center page, provides the scrollable widget titled, "Global Deaths" on the front or home page, which states that as of January 27, 2021, the estimate for our planet earth is that $2,173,965$ people have died from COVID-19 or a COVID-19 related condition. ${ }^{3}$
With the new demands placed upon health care facilities due to the coronavirus, suggestions to alleviate or reduce loneliness for an elderly person include providing music playing softly in the elderly person's room, provide television programs or a list of favorite movies that can be viewed when requested. Provide the means for family and friends to visit with video messaging, such as via a Facetime or a Facebook connection. These messages can even be recorded, so that the video message can be replayed, or pre-recorded to accommodate each person's schedule. Some facilities require that persons visit through a window. Chairs and portable tables can be provided next to the window, so that an elderly spouse or partner can sit comfortably and speak with their loved one-communicating with a cell phone or a "walkie talkie."

I thank the nurses, nurses-aids, the doctors, all staff members of medical care facilities who are serving us through this pandemic. I also thank the chaplains and the spiritual guides. The goodness of these persons, to serve the ill patient, and to serve their families, is amazing. Each day, they themselves, risk being infected by a coronavirus; yet they serve with their best efforts.

\section{REFERENCES}

1. The City of San Angelo, Texas. Website. https://www.cosatx. us/Home/Components/News/News/5258/17. Accessed January $27,2021$.

2. The Centers for Disease Control and Prevention (CDC). See the table: Place of Death. Website. https://www.cdc.gov/nchs/ covid19/mortality-overview.htm. Accessed January 27, 2021.

3. The John Hopkins University and Medicine website. See the widget "Global Deaths" Web site. https://coronavirus.jhu.edu/ map.html. Accessed January 27, 2021. 